CURRENT RESEARCH JOURNAL OF PHILOLOGICAL SCIENCES 2(9): 29-34,

September 2021

DOI: https://doi.org/10.37547/philological-crjps-02-09-07

ISSN 2767-3758

(C2021 Master Journals

Crossref do

\title{
PHRASES WITH AYAK (FOOT) COMPONENTS IN TURKISH AND THEIR CLASSIFICATION
}

\section{Sadaf Djumaliyevna Shabanova}

Teacher, Department Of "Turkish Philology", Faculty Of "Turkic Studies", Tashkent State University Of Oriental Studies, Uzbekistan

\section{ABSTRACT}

An important part of phraseology consists of somatic component expressions, the generality of which is reflected in the number of somatic phraseological units, their semantic and functional features in speech and their components.

Somatic component phraseologies, including head/baş, eye/göz, hand/el and foot/ayak component lexemes, seem to be actively involved in revealing the commonalities of the customs, traditions, and daily lives of the peoples of the world.

The purpose of this study is to explain the classification of phrases with a foot (foot) component and their semantic features.

KEYWORDS: - Ayak (foot) component, component, phrase, classification of phrases.

\section{INTRODUCTION}

There are ayak - foot, bacak - foot/ boldir, kalça thigh, diz - knee, bacak/ baldır - shin, topuk - heel words in Turkish that describe the components of "foot". Of these components, the foot is the main component that forms the foot component expressions. Phrases formed in the presence of the remaining components are few in number. There are no phrases with kalça -thigh of the above components. The study of the semantic properties of the phrase "foot" has shown that they are mainly used to describe the appearance, character, position, movement of a person. There are also a small number of expressions that describe society and human relations.
Phrases with a "foot" component in Turkish can be grouped as follows:

1. Ayak - foot component expressions.

2. Diz - knee component expressions.

3. Bacak/ baldır - foot / shin component expressions.

4. Topuk - heel component expressions.

Ayak - foot component expressions

\section{T HE MAIN FINDINGS AND RESULTS}

The largest group of "foot" component phrases in Turkish language consists of ayak - foot component phrases. The number of these phrases is 41 . Most of the ayak - foot component phrases are positive and the rest are negative. Let's talk about positive 
CURRENT RESEARCH JOURNAL OF PHILOLOGICAL SCIENCES 2(9): 29-34,

September 2021

DOI: https://doi.org/10.37547/philological-crjps-02-09-07

ISSN 2767-3758

(C2021 Master Journals

Crossref do

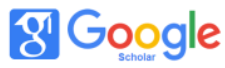

Accepted20 $0^{\text {th }}$ September, 2021 \& Published 25 $5^{\text {th }}$ September, 2021

phrases first, and then negative ones.

The phrase "Ayakları yere değmemek" - "feet not touching the ground" means "to enjoy, to be happy": "Üniversiteyi kazanmış; sevinçten uçuyor, ayakları yere değmiyor." - He entered the university, flying with joy, his feet not touching the ground. "Nişanlandığından beri ayakları yere değmiyor." Her feet have not touched the ground since she was engaged. This phrase, which expresses positive content, expresses a person's feelings.

The phrase "Ayağını denk almak" - "get your foot straight" means "uyanık ve sakıngan davranmak" "be alert and careful". Masalan: "Eğer ayağını denk almazsan o adamlar başına bir iş açacaklar senin." If you don't step on the right foot, those people will do something to you. This negative phrase described human actions.

The phrase "Ayağını yorganına göre uzatmak" "stretch your legs towards the bed" means "giderini,gelirine uydurmak" - "keladigan pulini xarajatiga mos keltirmoq". This expression refers to a person's economic status. For example: "Ayağını yorganına göre uzatmazsan, olacaklara da hazır olmalısın." - You also need to be prepared for what will happen if you do not stretch your legs towards the bed. "Aylin, ev alırken ayağını yorganına göre uzatmadığı için şimdi zorluk çekiyordu." - When Aileen got home, she was struggling to keep her feet on the bed.

If the phrase "Ayakları geri geri gitmek" -0 is translated into Uzbek verbatim, "legs go back", is an alternative to the Uzbek phrase "not to pull the leg". Because the phrase "bir yere giderken istemeye istemeye gitmek" means "reluctantly leaving when you're going somewhere". For example: "Böyle yapılınca misafirliğe giderken ayaklarım geri gider." - After that, when I go to a party, my leg goes back.

"Ayaklarım geri gidiyor çünkü o ev beni huzursuz ediyor." - My legs are slipping back because that house is bothering me. This phrase also expresses human feelings.

Bacak - foot / thigh component expressions

The main meaning of the word "Bacak" is "vücudun kasıktan tabana kadar olan bölümü" - "the part of the body from the pelvis, that is, from the abdomen and thighs to the heel", which means "thigh": "Yorgun vücudunu zahmetle taşıyan ince bacakları üstünde doğruldu." - He recovered his tired body over his slender legs, which he carried with a thousand toils. The second meaning of the word is "an organ in an animal that can walk or jump" - "an organ that can walk or jump in animals".

The word "Bacak" literally means "bazı șeylerin yerden yüksekçe durmasını sağlayan dayak, destek veya bunlardan her biri, ayak" - "a stick, a handle, or each of these, a foot, that keeps some things above the ground." For example: "İpleri sedirlerin bacaklarına doladılar". "The ropes are wrapped around the legs of the chairs".

"İskemlenin bir bacağı çıkmış." - One of the legs of the bench is out.

The word bacak also means "valet" in card games. There are not many phrases with bacak components. There are 10 phrases with this component in the Turkish Explanatory Dictionary and the Turkish Dictionary of Articles. Most of these component expressions have a negative connotation, and very few have a positive or neutral meaning.

"Bacak kadar" means "like a thigh". The term is used for children and means "small, juvenile". The phrase is a synonym for "finger" in Uzbek. The term is used to describe a person's appearance. For example: "Koskoca adam bacak kadar çocukla uğraşmaz." An adult does not deal with a child like a finger. 
CURRENT RESEARCH JOURNAL OF PHILOLOGICAL SCIENCES 2(9): 29-34,

September 2021

DOI: https://doi.org/10.37547/philological-crjps-02-09-07

ISSN 2767-3758

(C)2021 Master Journals

Crossref doi

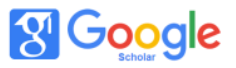

Accepted20 $0^{\text {th }}$ September, 2021 \& Published 25 $5^{\text {th }}$ September, 2021

The phrase "Bacak kadar boyu var türlü türlü huyu var" is literally translated into Uzbek as "tall as a leg, with different swords". The phrase "yaşı küçük ama çeşitli alışkanlıklar, huylar edinmiş anlamında söylenir" means "young, but with different habits and behaviors".

"Bacaklari kopmak" - "thigh amputation" means "gezmekten çok yorulmuş olmak"- "very tired of rotation". For example: "bacaklarım koptu". Let's sit here for a while, my legs are broken.

The phrase "Baldır bacak" is used in reference to "baldıra değin görülecek biçimde açık saçık durumdaki kadın bacağı" - "a woman's leg that is clearly visible to the ankles". The term is used to describe a person's appearance.

The word "Baldır bacak göstermek" is close to the phrase "baldır bacak" mentioned above, and "(kadın) çok açılıp saçılmak" means "too open for a woman." The term is also used to describe a person's appearance.

The phrase "Şeytanın art bacağı" - "the devil's hind leg" is used for children, and "çok afacan ve yaramaz (çocuk)" means "very naughty and naughty (child)". This phrase refers to the character of a person.

The word "Baldır" means "thigh" and "bacağın dizden ayak bileğine kadar olan bölümü, incik" means "the part of the moon from the knee to the ankle, the leg". For example: "Dizlerinde,baldırlarında sızı kalmadı" - No pain in the knees, legs.

The word "Baldır" means "thigh" and "bu bölümün yumuşak ve şişkin olan arka tarafı" means "the back of this section is soft and swollen."

There are only two phrases in Turkish with the word "Baldır" - "thigh". One of them is the phrase "baldır bacak" - "thigh -foot", the meaning of which we discussed in the analysis of the phrase "bacak". The second is the phrase baldırı çıplak.
"Baldırı çıplak" - "bare thigh". The phrase means "işsiz güçsüz, serseri, başı boş" - "unemployed, weak, lazy, and idle". For example, in the following examples, the phrase means "helpless", and describes the condition of people: "Baldırı çıplak insanlara yardım etmek gerekir" - We need to help those who are not able to work.

"Baldırı çıplak olmak ayıp değil ama emek vermeye hazır hale gelmemiz gerekir" - "It's not a crime to be unemployed, but we have to be ready to work".

In the following example, the phrase studied is used in a negative sense: "Sokaklar baldırı çıplaklardan geçilmiyor" - "It's impassable on the streets".

Diz - knee component expressions

The word "Diz" means "knee" and "kaval, baldır ve uyluk kemiklerinin birleştiği yer" means "the joint of the pelvis, legs and thighs". For example: "Düșen çocuğun dizi kanıyor". - "The fallen boy's knee is bleeding".

"Köşeye yaslanmış, bir dizini altına almış, öteki dizini dikmiş, kolunu da uzatmış, anlatıyordu." Leaning into a corner, he brought one knee down, straightened the other, and stretched out his hand to speak.

The word means "the top of the bent leg when sitting". For example: "Çocuğu dizine oturttu" - "He put the boy on his knees".

The word "Diz" means "knee" and "(pantolonda) dize rastlayan yer" means "the place where (in the pants) falls on the knee". For example: "Pantolonun dizleri aşınmış" - Shim's knees are worn out.

The number of diz component phrases in Turkish is 21 . This type of expression has a mostly negative connotation, and a small fraction has a neutral connotation.

The words "Diz çökmek" and "kneel" mean the following:

The main meaning of this phrase can be interpreted 
CURRENT RESEARCH JOURNAL OF PHILOLOGICAL SCIENCES 2(9): 29-34,

September 2021

DOI: https://doi.org/10.37547/philological-crjps-02-09-07

ISSN 2767-3758

(C)2021 Master Journals

Crossref doi

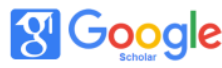

Accepted20 ${ }^{\text {th }}$ September, 2021 \& Published 25 ${ }^{\text {th }}$ September, 2021

as "dizlerini yere koyarak oturmak" - "sit on your knees".

"Diz çökmek" - "kneeling" means "yenilgiyi kabul etmek, boyun eğmek, baş eğmek" - "accepting defeat, bowing, bowing": "Düşman, diz çökmek zorunda kaldı" - The enemy is obliged to kneel.

"Diz dize" means "knee-to-knee" and "dizleri birbirine değecek biçimde birbirine yakın olarak" means "to be so close as to touch the knees":

Evimizin önünden dere akar denize

Yaşlansaydık sevdiğim senin ile diz dize

Karayemiş dalının açtı beyaz çiçeği

Bu sevdadan fayda yok geçirmişiz zamani.

In front of our house a stream flows into the sea

As we grow older, we will kneel with our loved ones

The white flower of the blackberry branch has opened

There is no point in this trade, we are wasting our time.

The phrase "Diz dize oturmak" means "karşı karşıya ya da yan yana, birbirine iyice yaklaşmış olarak oturmak" - "to sit facing each other or side by side, very close to each other": "Kendi de diz dize gelecek kadar karşıma geldi oturdu" - "He came up to me on his knees".

"Seninle ben bir ağaç kovuğunda iki mantar gibiyiz, diz dize otururuz, bir yere gidemeyizç." - You and I are sitting side by side in a tree hole like two mushrooms, and we can't go anywhere.

The word "Dizleri kesilmek (veya tutmamak)" "The cut at the knees (or not)" means "dizlerinde derman, güç kalmamak" - "strain on the knees, lack of strength". For example: "uracıktan şuracığa yürüyemedim. Dizlerim kesiliverdi”. - I couldn't walk from here to here. There is no medicine left on my knees.

"Asansör bozuk, yedinci kata çıkıncaya kadar dizlerim kesildi." - The elevator was broken, and I had no strength left on my knees until I reached the seventh floor.

"Dizlerinin bağı çözülmek" - "clinging to your knees" means "korkudan, heyecandan, yorgunluktan ayakta duramayacak hâle gelmek" "going down to ask for something, begging too much". For example: "Yokuşu çıktım ama dizlerimin de bağıçözüldü" - "You see, one day he'll be on his father's lap".

The phrase "Dizlerinin bağı çözülmek" means "to untie the knees" and "korkudan, heyecandan, yorgunluktan ayakta duramayacak hâle gelmek" means "to the point where one cannot stand on one's feet out of fear, excitement and fatigue": "Yokuşu çıktım ama dizlerimin de bağıçözüldü". - "I came off the cliff, but my legs are so tired".

The phrase "Dizini dövmek" means "to strike the knee", and "çok pişman olmak" means "to be very sorry". For example: "Çocuklarını küçük yaşta eğitmezsen sonradan dizini döversin". - "If you don't raise your children from an early age, then you will regret it".

"Sana söyleyeyim onlardan uzak dur, sonradan dizlerini döversin." - I tell you, stay away from them or you will regret it later.

The phrase "Dize gelmek" - "to get on one's knees" has the following meanings:

1. the first meaning of the phrase is "güçlünün buyruğunu kabul eder duruma gelmek" "to come to a position of accepting the command of the strong".

2. The second meaning of the phrase "Dize gelmek" is interpreted as "yenilip teslim olmak" - "defeat and surrender": "Bizim kitabımızda dize gelmek yoktur!" - There is no defeat in our book.

3. "Dize gelen düşman kısa sürede şehri terk etmeye de başladı." - The defeated enemy soon began to leave the city as well.

4. The phrase "Dize getirmek" means "kendisine karşı geleni alt ederek buyruğunu dinler duruma getirmek, boyun eğdirmek" - "to overcome one's adversary, to obey his command, to submit". For example: "İki saatte düşmanı dize getirebiliriz" - "We can defeat the enemy in 
CURRENT RESEARCH JOURNAL OF PHILOLOGICAL SCIENCES 2(9): 29-34,

September 2021

DOI: https://doi.org/10.37547/philological-crjps-02-09-07

ISSN 2767-3758

(C2021 Master Journals

Crossref do

81 Google

Accepted20 $0^{\text {th }}$ September, 2021 \& Published 25 $5^{\text {th }}$ September, 2021

two hours".

"Milli güreşçimiz, bir günde iki rakibini dize getirdi."

- Our national wrestler defeated two opponents in one day.

"Dizinin dibi" means "below the knee" and "yanı

bașı" means "sideways". For example:

Üzüleceksek üzülelim be

Yalana sarma günahlara girme

Karışalım mı ele güne söyle

Ya da her an dizinin dibinde.

If we are upset, let's be upset,

Do not lie, do not sin.

Let's get involved, tell the day

Or in your head every moment.

"Diz boyu" - "knee-length" is used for "dize kadar (yükseklik veya alçaklık için)" - height or low, and means "up to the knee". For example: "Çukuru diz boyu kazmışlardı" - "They dug a hole knee-deep".

Topuk - heel component expressions

The word "Topuk" means "ayağın yuvarlakça olan alt bölümü" - "rounded lower part of the foot". The Uzbek translation of this word is "heel". For example: "Topuklarına kadar uzun saçları vardı" He had long hair down to his heels.

The second meaning of the word "Topuk" is "ökçe" "Topuk". For example: "Sıska kız, alışık olmadığı yüksek topuklarla yürümeye çalışıyordu" - "The thin girl was trying to walk in unusually high heels". "Topuk" - "tovon" komponenti ishtirokida ikki dona ibora mavjudligi aniqlandi, ikkala ibora ham neytral mazmunni anglatadi:

It was found that there are two phrases with the component "Topuk" - "heel", both phrases have a neutral meaning:

1. "Topuk çalmak" - "tovon chalmoq" iborasi "yürürken ayakların iç kemikleri birbirine çarpmak" - "yurayotganida oyoqlarining ichki tomondagi suyaklarini bir-biriga urmoq" degan mazmunni ifoda etadi. 1. The phrase "Topuk çalmak" - "to kick" means "yürürken ayakların iç kemikleri birbirine çarpmak" - "to hit the inner bones of the legs while walking".
2. The word "Topuk vurmak" means "to strike the heel" and "selamlamadan önce ayak topuklarını yan yana getirmek" means "to strike the heels of the feet together before greeting".

The word "Kalça" means "gövdenin arka bölümünde, bacakların birleștiği yerle bel arasındaki șișkin bölge" - "swollen part of the back of the body, between the joints of the legs and the waist", i.e. "thigh".

For example: "Sol kolunu yürürken hep kalçasına dayardı" - "He always rested his left hand on his thigh as he walked".

"Kısa süre önce düştünüz ve şimdi kalçanız çok ağriyor." - You fell a short time ago and now your number hurts.

It was found that there are no phrases in the Turkish language with the participation of the component "Kalça" - "thigh".

\section{Conclusion}

To conclude, the Turkish language has the words ayak - foot, bacak - foot/ boldir, kalça -thigh, diz knee, bacak/ baldır - shin, topuk - heel, which represent the "foot" components. The total number of expressions involving these components is 72 .

Phrases with a "foot" component in Turkish are divided into 4 groups:

1. Ayak - foot component expressions.

2. Diz - knee component expressions.

3. Bacak/ baldır - foot / shin component expressions.

4. Topuk - heel component expressions.

The largest group of phrases with the component "foot" in the Turkish language is the phrase with the foot component. The number of these expressions is 41. There are 10 Bacak/ baldır - foot / shin component phrases. The number of Diz - knee component phrases is 21 . There are no phrases involving "Kalça" - "thigh" of the above components. 
CURRENT RESEARCH JOURNAL OF PHILOLOGICAL SCIENCES 2(9): 29-34,

September 2021

DOI: https://doi.org/10.37547/philological-crjps-02-09-07

ISSN 2767-3758

(C)2021 Master Journals

Crossref dof 81 Google

Accepted20 th September, 2021 \& Published 25 $5^{\text {th }}$ September, 2021

\section{REFERENCES}

1. Yuldoshev B. (1993) Functional and methodological features of phraseological units in modern Uzbek literary language: Doctor of Philological Sciences. - Tashkent. - p. 24. (Йулдошев Б. Хозирги узбек адабий тилида фразеологик бирликларнинг функционалуслубий хусусиятлари: филол. фанлари д-ри ... дисс. автореф. - Тошкент, 1993. -24 б.)

2. Usmanova Sh.R. (1998) Somatic phraseology in Uzbek and Turkish languages: f.f. n. diss. Tashkent. - p. 136. (Усманова Ш.Р. Ўзбек ва турк тилларида соматик фразеологизмлар: ф.ф. н. дисс. - Тошкент, 1998. - 136 б.)

3. Nassiri M. (2015) Semantics and functioning of Russian phraseological units with componentssomatisms hand and foot. Abstract dissertation. Candidate of Philological Sciences Moscow: - p. 23. (Нассири М. Семантика и функционирование русских фразеологизмов с компонентами-соматизмами рука и нога. Автореферат дисс. ... кан. фил. наук. М.: 2015. $-23 \mathrm{c.})$

4. Ahat Ü. Karahanlıca ve eski anadolu metinlerinde deyimler, atasözleri ve kisa hikayeler. Yüksek lisans. -Elazığ, 1989. -145 s.

5. Hamidov H. Türkçede İnsan Vücuduyla Ilgili Deyimler // Türkçe'nin Sesi, Dergi. Sayı: Bahar. -Erzurum, 2003. $8 \mathrm{~s}$.

6. Aksoy Ö.A. Atasözleri ve Deyimler sözlüğü. İstanbul: İnkilap kitabevi, 2016. -1205 s.

7. Türkçe sözlük. 1k.-Ankara: Türk Dil Kurumu, 2010. $-2763 \mathrm{~s}$.

8. Annotated dictionary of the Uzbek language. Five volumes. Volume 5 - Tashkent: National Encyclopedia of Uzbekistan State Scientific Publishing House. 2006. - p. 563. (O'zbek tilining izohli lugati. Besh tomlik. 5-tom. Toshkent: O'zbekiston milliy ensiklopediyasi Davlat ilmiy nashriyoti, 2006. 563 b.)

9. Ismatullayeva, N. R. (2020). Expression of somatic physionimistic lacunas in Chinese and Uzbek languages. In Наука и инновации в XXI веке: актуальные вопросы, открытия и достижения (pp. 127-129).

10. Khudoyorovich, K. K., Rasuljanovna, I. N., Khalmuratovna, R. Z., \& Eshkobilovna, K. D. (2020). The Issues of Word Choice in Fiction Translation. International Journal of Psychosocial Rehabilitation, 24(04). 